\title{
Rancang Bangun Sistem Informasi Persediaan Obat Berbasis Web
}

\author{
Daniel Lumbantoruan ${ }^{1}$, Retno Sari ${ }^{2}$ \\ ${ }^{1}$ Sekolah Tinggi Manajemen Informatika dan Komputer Nusa Mandiri/Sistem Informasi \\ ${ }^{2}$ Sekolah Tinggi Manajemen Informatika dan Komputer Nusa Mandiri/Teknik Informatika \\ e-mail: 1danielumbantoruan@gmail.com, ${ }^{2}$ retno.rnr@nusamandiri.ac.id

\begin{tabular}{ccc}
\hline Diterima & Direvisi & Disetujui \\
$16-02-2021$ & $04-03-2021$ & $10-03-2021$ \\
\hline
\end{tabular}

\begin{abstract}
Abstrak - Sistem inventory merupakan suatu sistem guna mengetahui persediaan barang yang ada pada gudang. Sistem inventori sendiri telah dikembangkan pada suatu tempat dengan berbagai macam teknologi maupun sistem. Permasalahan yang kerap kali terjadi di Apotek Mediko Farma Jakarta adalah belum adanya sistem inventory obat sehingga belum bisa mengontrol stok barang yang tersedia dan belum terkomputerisasi. Maka dari itu penelitian ini ditujukan untuk membangun suatu sistem inventori yang berbasis web, agar memudahkan dalam menjaga persediaan yang ada secara tepat dan terperinci. Berdasarkan dari hasil riset yang telah dilakukan di Apotek Mediko Farma Jakarta sistem informasi persediaan barang diolah oleh bagian Administrasi. Hal ini memang cukup rumit mengingat banyaknya jumlah obat yang menjadi tanggug jawab, hal ini tentu membutuhkan pengelolaan yang tersistemasi dan terkoordinasi dengan baik. Agar memudahkan proses keluar masuk obat, maka diperlukan sebuah komunikasi yang cukup baik antara Administrasi dan pihak Kasir. Dengan demikian proses persediaan obat pada Apotek dapat terjaga dengan baik.
\end{abstract}

Kata Kunci: Sistem Informasi, Persediaan Obat, Aplikasi Berbasis Web

\section{PENDAHULUAN}

Cepatnya perkembangan komputer, telah banyak digunakan sebagai alat untuk mempercepat pemrosesan data. Sarana dan prasarana yang memadai telah memberikan bantuan untuk peningkatan teknologi untuk membantu pengambilan keputusan yang cepat dan menyelesaikan pekerjaan dengan cepat dan efisien.

Komputer merupakan suatu alat yang dapat digunakan untuk meningkatkan kinerja, dikarenakan dengan komputer semua kegiatan dapat menjadi lebih efektif dan efisien.

Teknologi komputer yang saat ini digunakan Apotek Mediko Farma di Jakarta masih bersifat manual operasional dan belum terkomputerisasi, artinya proses pembukuan masih dilakukan melalui pencatatan manual dan belum terintegrasi. Sederhanakan dan hitung secara akurat proses inventarisisasi komoditas dan jenis komoditas. Mendorong perusahaan untuk menerapkan sistem informasi komputer.

Apotek Citra Farma memproses data persediaan obat (seperti proses pengecekan persesdiaan obat, obat yang masuk dan keluar), masih dilakukan melalui pencarian sederhana, sehingga pegawai gudang akan menemui kendala saat menghitung persesiaan obat dan proses pengecekan inventaris jenis obat yang digunakan masih tersedia yang akan mengakibatkan pelaporan data tidak akurat dan kemungkinan kehilangan data karena belum menggunakan database(Afni, Pakpahan, \& Zaman, 2019).

PT. Sakura Yasa Proma pengolahan datanya masih manual yang menyebabkan kinerja perusahaan menjadi terhambat dan terdapat kekeliruan(Nawang, Kurniawati, \& Duta, 2017).

Untuk tujuan perubahan, sistem komputersisi ini diharapkan dalam proses pengelolaan persediaan menjadi lebih efektif dan efisien, serta penyajian laporan persediaan lebih akurat dan tepat waktu(Sari \& Nuari, 2017).

Pengendalian persediaan diperlukan untuk mengetahui kelancaran proses produksi serta efektivitas dan efisiensi perusahaan(Sampeallo, 2012).

\section{TINJAUAN LITERATURE}

\section{A. Konsep Dasar Sistem}

Sistem adalah seperangkat elemen yang membentuk kumpulan atau prosedurprosedur/bagan- bagan pengolahan yang mencari suatu tujuan bagian atau tujuan bersama dengan mengoperasikan data. Menurut pandangan Yunita dkk dalam (Mulyani, 2017) Sistem dapat diartikan sebagai kumpulan komponen-komponen yang bekerja sama guna memenuhi tujuan bersama. 
Misalnya bidang organisasi keuangan, operasi dan pemasaran memiliki tujuan yang sama untuk mencapai tujuan perusahaan secara keseluruhan.

\section{B. Pengertian Persedian}

Menurut Sumiati persediaan merupakan salah satu komponen kerja mempunyai tingkat likuiditas yang lebih rendah dibandingkan dengan piutang (Indrawati, 2019).

\section{Unified Modelling Language}

Menurut Habibi dkk dalam (Marina, Wahjono, Syaban, \& Suarni, 2018)Unified Modelling Language (UML) adalah sebuah bahasa yang sudah menjadi standar di dalam industry untuk visualisasi, merancang dan mendokumentasikan sistem perangkat lunak.

Berikut ini adalah diagram-diagram yang bisa digambarkan dengan UML:

1. Use Case Diagram

2. Class Diagram

3. Statechart Diagram

4. Activity Diagram

5. Sequence Diagram

6. Collaboration Diagram

7. Component Diagram

8. Deployment Diagram

9. Package Diagram

Unified Modeling Language (UML) merupakan strandar yang relatif terbuka yang dikontrol oleh Object Management Group (OMG), sebuah konsorsium terbuka yang terdiri dari banyak perusahaan. OMG dibentuk untuk membuat standarstandar yang mendukung interoperabilitas, khususnya interoperabilitas sistem berorientasi objek. OMG mungkin lebih dikenal dengan standarstandar COBRA (Common Object Request Broker Architecture).

\section{Entity Relationship Diagram}

Menurut Sulianta dalam (Indrawati, 2019)

Entity Relationship Diagram (ERD) adalah diagram yang digunakan sebagai perancangan tabel-tabel yang nantinya akan diimplementasikan pada basis data. Berikut adalah 3 elemen ERD yaitu entitas, atribut dan relasi.

Menurut Hoffers, Ramesh dan Topi dalam (Sudradjat, 2019) ERD merupakan representasi grafis dari data dengan menggunakan entitas sebagai category data dan hubungan untuk asosiasi antar entitas.

\section{E. Logical Record Structured (LRS)}

Menurut Pratama LRS merupakan transformasi dari penggambaran ERD dalam bentuk yang lebih jelas dan mudah dipahami (Rosidin \& Lubis, 2017)

\section{METODE PENELITIAN}

$$
\text { System Development Lyfe Cycle (SDLC) }
$$

adalah metode yang digunakan utnuk mengembangkan sistem(Mulyani, 2017). Model waterfall digunakan untuk membuat model pengembangan perangkat lunak pada website ini. Waterfall merupakan salah satu contoh prses penyusunan sistem informasi akuntansi, dalam proses ini semua kegiaan harus direncanakan dan diatur sebelum dilanjutkan(Adhawiyah, Kumaladewi, \& Caturutami, 2017).

A. Analisa Kebutuhan Sistem

Pada tahap ini mempelajari sistem web untuk menentukan antarmuka, kebutuhan data, kebutuhan fungsional yang dibutuhkan dan solusi perankat lunak yang dibutuhkan untuk pengembangan sistem yang akan dikembangkan.

B. Design

Pada tahap ini dilakukan desai database menggunakan diagram entity relatioship diagram (ERD), logical record stucture (LRS) dan Unified Modeling Language (UML).

C. Code Generation

Pembuatan kode program di tahap ini menggunakan bahasa pemrograman php, html dan java script.

D. Testing

Dalam pembuatan program ini dilakukan pengujian menggunakan blackbox testing untuk meminimalkan kesalahan (error) dan memiliki keluaran yang tepat sesuai dengan harapan.

E. Support

Pengembangan sistem untuk pemrograman, memiliki tujuan untuk memprediksi perkembangan dan erubahan sistem yang terjadi. Dalam pengembangan, perangkat keras telah mendukung semua program digunakan, dan perangkat lunak yang digunakan dapat diimplementasikan dalam berbagai data operasi. Menurut Yunida dkk[4], sistem dapat diartikan sebagai kumpulan komponen yang secara bersama-sama mencapai suatu tujuan bersama. Misalnya, organisasi keuangan, operasi dan area pemasaran memiliki tujuan yang sama untuk mencapai tujuan perusahaan secara keseluruhan.

\section{HASIL DAN PEMBAHASAN}

\section{A. Analisa Kebutuhan}

Pada penelitian ini terdapat 2 halaman, yaitu halaman administrasi dan halaman kasir. Berikut kebutuhan sistem dari masing-masing halaman

Halaman Administrasi :

Administrator web dibutuhkan untuk dapat melakukan hal-hal sebagai berikut:

A1. Admin dapat mengakses menu utama.

A2. Admin dapat mengakses Menu Home

A3. Admin dapat mengakses menu User 
A4. Admin dapat mengakses menu Kategori

A5. Admin dapat mengakses menu Barang

A6. Admin dapat mengakses menu Supplier

A7. Admin dapat mengakses menu Lokasi

A8. Admin dapat mengakses menu Request Barang

A9. Admin dapat mengakses menu Barang Masuk

A10. Admin dapat mengakses menu Laporan Stok Barang

A11. Admin dapat mengakses menu Laporan Masuk A12. Admin dapat mengakses menu Barang Keluar A13. Admin dapat mengakses menu LogOut

Halaman Kasir :

B1. Kasir dapat mengakses menu Home

B2. Kasir dapat mengakses menu Transaksi

B3. Kasir dapat mengakses menu Laporan.

B4. kasir dapat melihat profile

B5. Kasir dapat mengakses menu Transaksi

B6. Kasir dapat mengakses menu Barang Keluar

B7. B5. Kasir dapat mengakses menu Laporan

B8. Kasir dapat mengakses menu Laporan Stok Barang.

\section{B. Desain}

1) Use Case Diagram

Berikut gambar use case diagram admin yang dapat dilihat pada gambar 1, use case diagram kasir pada gambar 2 .

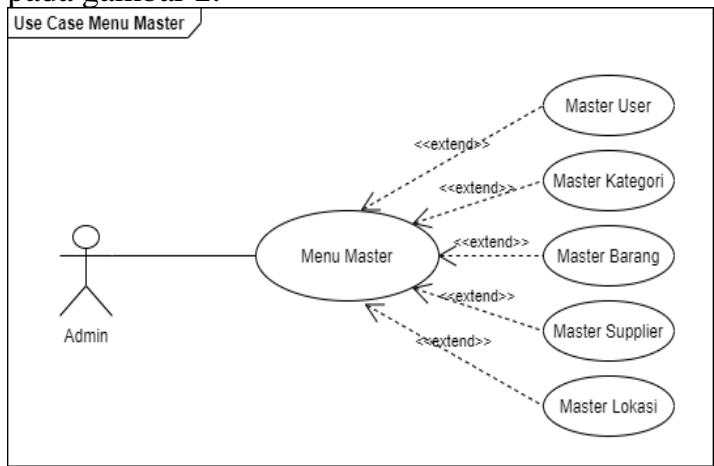

Sumber : (Hasil Penelitian, 2020)

Gambar 1. Use Case Diagram Admin

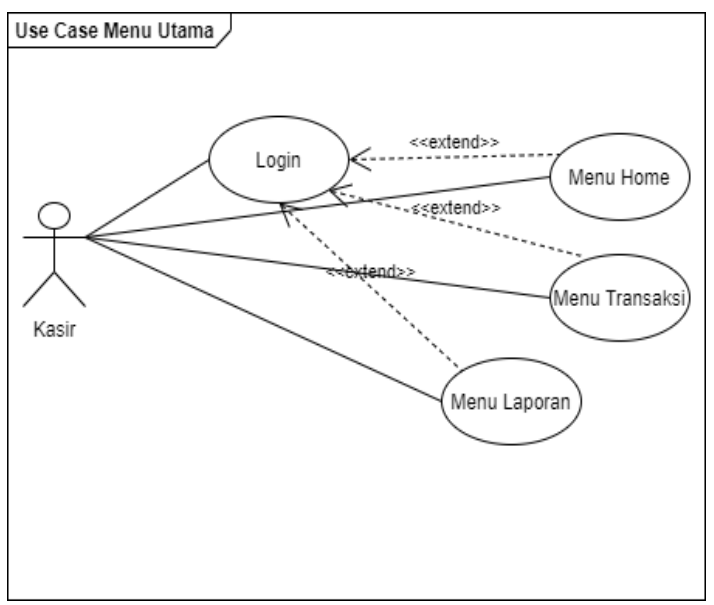

Sumber : (Hasil Penelitian, 2020)

Gambar 2. Use Case Diagram Pengajar
2) Activity Diagram

Berikut activity diagram admin dan kasir.

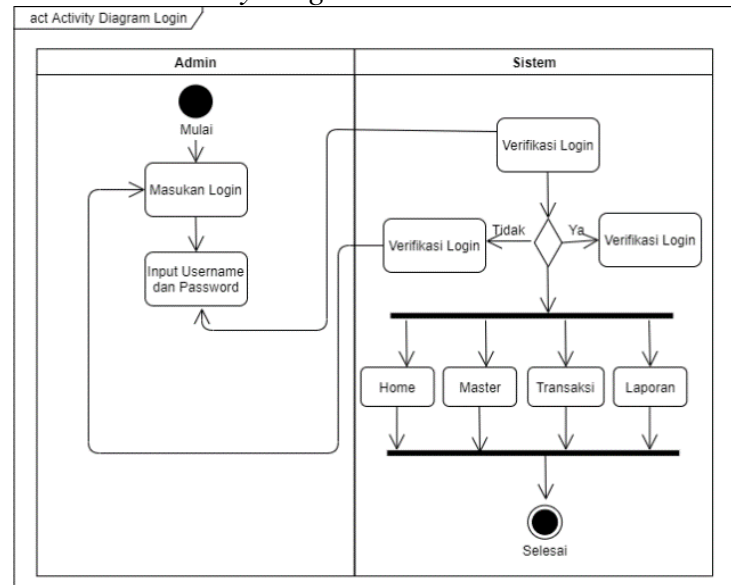

Sumber : (Hasil Penelitian, 2020)

Gambar 3. Activity Diagram Halaman Admin

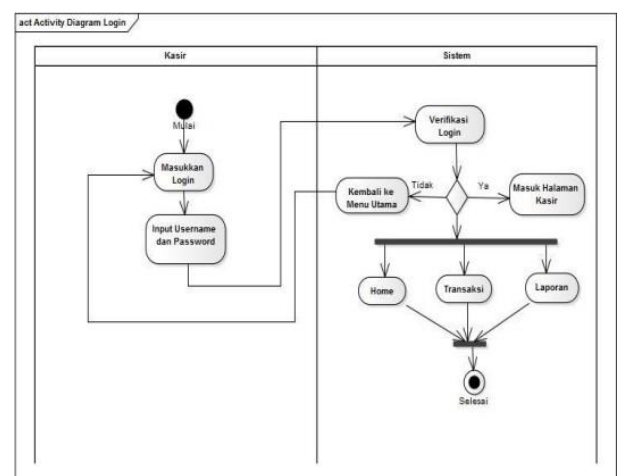

Sumber : (Hasil Penelitian, 2020)

Gambar 4. Activity Diagram Halaman Admin

3) Entity Relationship Diagram

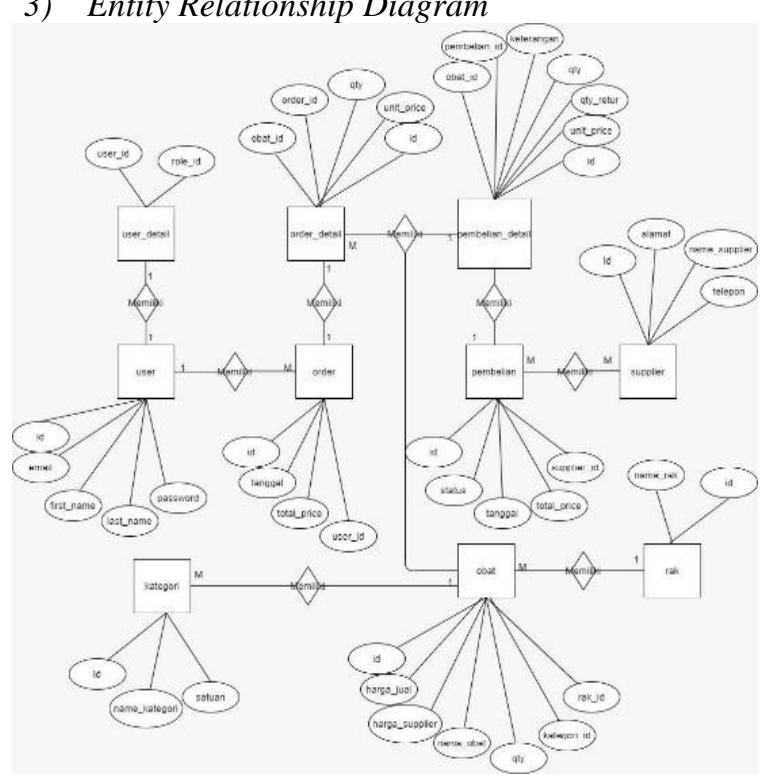

Sumber : (Hasil Rancangan, 2020)

Gambar 5. Entity Relationship Diagram (ERD) 
4) Logical Record Structure (LRS)

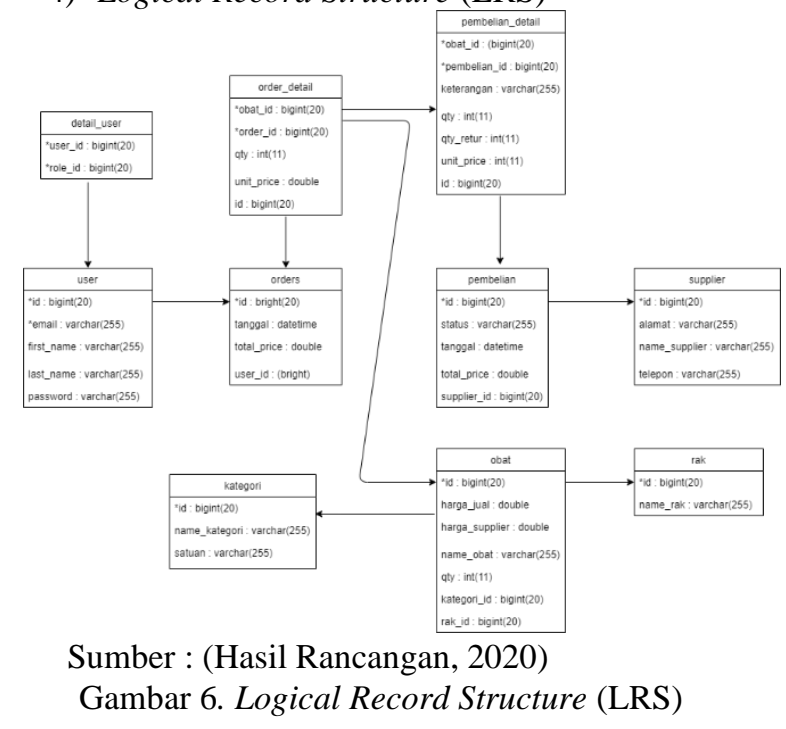

\section{5) User Interface}

User interface merupakan sarana komunikasi antara user dengan sistem. Berikut beberapa usert interface yang dibuat.

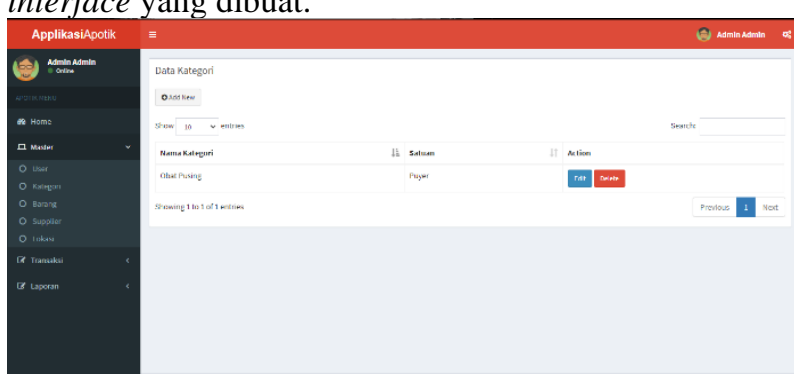

Sumber : (Hasil Rancangan, 2020)

Gambar 7. Halaman menu data kategori

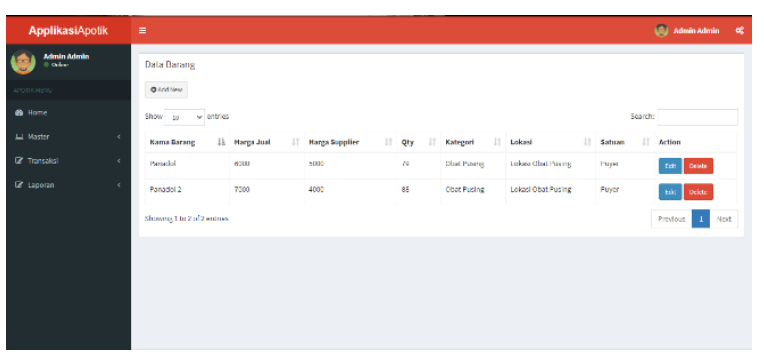

Sumber : (Hasil Rancangan, 2020)

Gambar 8. Halaman menu data barang

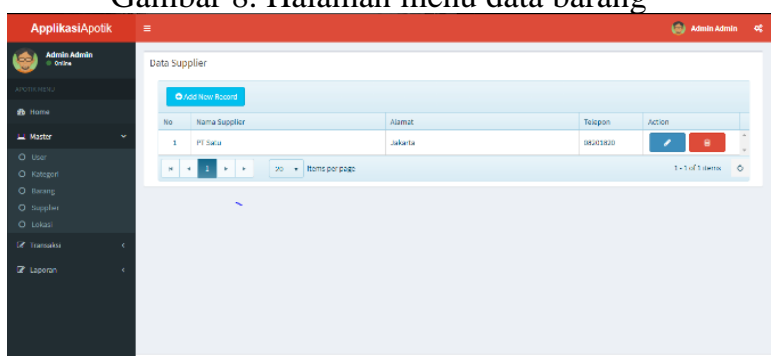

Sumber : (Hasil Rancangan, 2020)

Gambar 9. Halaman menu data supplier

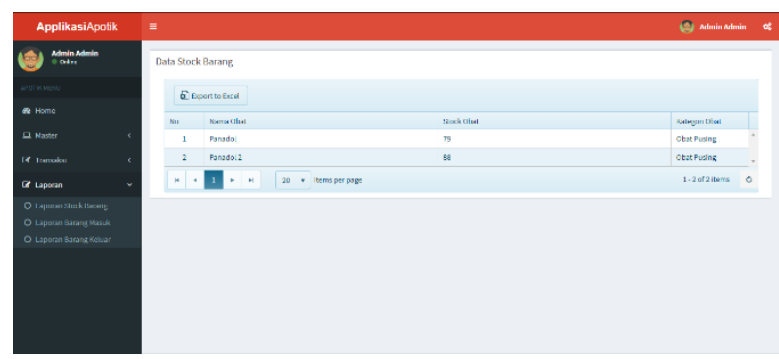

Sumber : (Hasil Rancangan, 2020)

Gambar 10. Halaman menu stok barang

\section{Code Generation}

Untuk mendukung pembuatan sistem ini penulis menggunakan bahasa pemrograman berbasis objek, Hyperlink Text Markup Languange (HTML), php dan java script.

\section{Testing}

Untuk pengujian menggunakan blackbox testing. Berikut tabel blackbox testing untuk form login admin pada tabel 1 dan blackbox testing untuk form menu utama halaman admin pada tabel 2 .

Tabel 1. Blackbox testing form login admin

\begin{tabular}{|c|c|c|c|}
\hline $\begin{array}{l}\text { Skenario } \\
\text { Pengujian }\end{array}$ & Test case & $\begin{array}{l}\text { Hasil yang } \\
\text { diharapkan }\end{array}$ & $\begin{array}{l}\text { Hasil } \\
\text { Pengujian }\end{array}$ \\
\hline $\begin{array}{l}\text { Username } \\
\text { dan } \\
\text { password } \\
\text { tidak diisi } \\
\text { kemudian } \\
\text { tombol } \\
\text { sign in }\end{array}$ & $\begin{array}{l}\text { Username: } \\
\text { (kosong) } \\
\text { Password: } \\
\text { (kosong) }\end{array}$ & $\begin{array}{l}\text { Sistem akan } \\
\text { menolak } \\
\text { akses dan } \\
\text { muncul } \\
\text { peringatan } \\
\text { "please fill } \\
\text { out this } \\
\text { field" }\end{array}$ & $\begin{array}{c}\text { Sesuai } \\
\text { harapan }\end{array}$ \\
\hline $\begin{array}{l}\text { Username } \\
\text { diisi dan } \\
\text { password } \\
\text { tidak diisi } \\
\text { kemudian } \\
\text { klik sign } \\
\text { in }\end{array}$ & $\begin{array}{l}\text { Username: } \\
\text { (benar) } \\
\text { Password: } \\
\text { (kosong) }\end{array}$ & $\begin{array}{l}\text { Sistem akan } \\
\text { menolak } \\
\text { akses dan } \\
\text { muncul } \\
\text { peringatan } \\
\text { "please fill } \\
\text { out this } \\
\text { field" }\end{array}$ & $\begin{array}{l}\text { Sesuai } \\
\text { harapan }\end{array}$ \\
\hline $\begin{array}{l}\text { Username } \\
\text { tidak diisi } \\
\text { dan } \\
\text { password } \\
\text { diisi } \\
\text { kemudian } \\
\text { klik sign } \\
\text { in }\end{array}$ & $\begin{array}{l}\text { Username: } \\
\text { (kosong) } \\
\text { Password: } \\
\text { (diisi) }\end{array}$ & $\begin{array}{l}\text { Sistem akan } \\
\text { menolak } \\
\text { akses dan } \\
\text { muncul } \\
\text { peringatan } \\
\text { "please fill } \\
\text { out this } \\
\text { field" }\end{array}$ & $\begin{array}{l}\text { Sesuai } \\
\text { harapan }\end{array}$ \\
\hline $\begin{array}{l}\text { Username } \\
\text { diisi dan } \\
\text { password } \\
\text { diisi } \\
\text { kemudian }\end{array}$ & $\begin{array}{l}\text { Username: } \\
\text { (benar) } \\
\text { Password: } \\
\text { (benars) }\end{array}$ & $\begin{array}{l}\text { Sistem akan } \\
\text { otomatis } \\
\text { membawa } \\
\text { ke "Home" }\end{array}$ & $\begin{array}{l}\text { Sesuai } \\
\text { harapan }\end{array}$ \\
\hline
\end{tabular}




\begin{tabular}{|l|l|l|l|}
\hline $\begin{array}{l}\text { klik sign } \\
\text { in }\end{array}$ & & & \\
\hline
\end{tabular}

Tabel 2. Balckbox testing menu utama halaman admin

\begin{tabular}{|c|c|c|c|}
\hline $\begin{array}{c}\text { Skenario } \\
\text { Pengujian }\end{array}$ & $\begin{array}{l}\text { Test } \\
\text { Case }\end{array}$ & $\begin{array}{l}\text { Hasil Yang } \\
\text { Diharapkan }\end{array}$ & $\begin{array}{c}\text { Hasil } \\
\text { Pengujian }\end{array}$ \\
\hline $\begin{array}{l}\text { Pilih menu } \\
\text { master }\end{array}$ & $\begin{array}{l}\text { Klik } \\
\text { menu } \\
\text { user }\end{array}$ & $\begin{array}{l}\text { Sistem akan } \\
\text { menampilkan } \\
\text { halaman user }\end{array}$ & $\begin{array}{c}\text { Sesuai } \\
\text { Harapan }\end{array}$ \\
\hline $\begin{array}{l}\text { Pilih menu } \\
\text { user }\end{array}$ & $\begin{array}{c}\text { Klik } \\
\text { menu } \\
\text { tambah } \\
\text { user }\end{array}$ & $\begin{array}{l}\text { Sistem akan } \\
\text { menampilkan } \\
\text { form } \\
\text { tambahan } \\
\text { user, seperti } \\
\text { fist name, } \\
\text { last name, } \\
\text { email, } \\
\text { password, } \\
\text { dan role } \\
\text {,sistem akan } \\
\text { menampilkan } \\
\text { menu user. }\end{array}$ & $\begin{array}{c}\text { Sesuai } \\
\text { Harapan }\end{array}$ \\
\hline $\begin{array}{l}\text { Pilih menu } \\
\text { master }\end{array}$ & $\begin{array}{c}\text { klik } \\
\text { menu } \\
\text { kategori }\end{array}$ & $\begin{array}{l}\text { Sistem akan } \\
\text { menampilkan } \\
\text { halaman } \\
\text { kategori }\end{array}$ & $\begin{array}{c}\text { Sesuai } \\
\text { Harapan }\end{array}$ \\
\hline $\begin{array}{l}\text { Pilih menu } \\
\text { kategori }\end{array}$ & $\begin{array}{c}\text { pilih } \\
\text { menu } \\
\text { tambah } \\
\text { kategori }\end{array}$ & $\begin{array}{l}\text { Sistem akan } \\
\text { menampilkan } \\
\text { form untuk } \\
\text { penambahan } \\
\text { name } \\
\text { kategori, dan } \\
\text { satuan } \\
\text { kategori obat }\end{array}$ & $\begin{array}{c}\text { Sesuai } \\
\text { Harapan }\end{array}$ \\
\hline $\begin{array}{c}\text { Menghapus } \\
\text { salah satu } \\
\text { data obat }\end{array}$ & $\begin{array}{l}\text { klik } \\
\text { delete }\end{array}$ & $\begin{array}{l}\text { Sistem } \\
\text { akan } \\
\text { menghapus } \\
\text { secara } \\
\text { otomatis }\end{array}$ & $\begin{array}{c}\text { Sesuai } \\
\text { Harapan }\end{array}$ \\
\hline $\begin{array}{l}\text { Mengubah } \\
\text { salah satu } \\
\text { data obat }\end{array}$ & $\begin{array}{l}\text { Klik } \\
\text { edit }\end{array}$ & $\begin{array}{l}\text { Sistem akan } \\
\text { mengubah } \\
\text { tampilan } \\
\text { form barang } \\
\text { yaitu name } \\
\text { barang, } \\
\text { kategori, } \\
\text { lokasi, harga } \\
\text { jual, harga } \\
\text { supplier, qty. } \\
\text { Sistem akan } \\
\text { kembali } \\
\text { kemenu } \\
\text { barang }\end{array}$ & $\begin{array}{c}\text { Sesuai } \\
\text { Harapan }\end{array}$ \\
\hline
\end{tabular}

\section{KESIMPULAN}

Menyimpulkan berdasarkan hasil pengamatan dan pengembangan sistem yang telah dilaksanakan mulai dari tahap analisis sampai ke tahap perancangan maka dapat di simpulkan bahwa pengolahan data yang bersifat manual menyebabkan ketidak efisienan dalam pengolahan data pembelian. Untuk itu dikembangkannya sistem lama menjadi sistem informasi pembelian yang berbasis komputer diharapkan dapat memiliki keunggulan tersendiri dibandingkan dengan sistem lama yang masih dilakukan secara manual. Keunggulan tersebut diantaranya adalah:

1. Kecepatan pemrosesan data, mengurangi terjadinya kehilangan data akibat dokumendokumen berupa kertas yang seringkali hilang.

2. Dapat mengetahui informasi secara cepat, tepat dan akurat.

3. Dengan menggunakan komputer, pencatatan transaksi menjadi lebih cepat dan akurat jika dibandingkan dengan pencatatan yang masih menggunakan cara manual.

4. Dengan komputer juga dapat menyimpan data obat yang lebih banyak didalam database sehingga tidak memerlukan tempat penyimpanan dokumen, dan dapat membuat laporan yang akurat dengan waktu yang lebih cepat, apabila kita ingin mengetahui isi dokumen tanpa harus membuka satu persatu lembaran-lembaran dokumen bertumpuk

5. Dengan pemanfaatan komputer yang sedemikian rupa secara tidak langsung dapat membanggakan ilmu pengetahuan dan teknologi yang sudah ada

Kelebihan dari penelitian ini adalah memudahkan Admin dan Kasir dalam mengakses web yang telah dibuat, Diharapkan dengan sistem baru yang telah komputerisasi ini dapat menyederhanakan proses kerja, memperkecil jumlah kesalahan yang dibuat. Sedangkan kekurangan penelitian ini adalah hanya ditujukan untuk proses persediaan obat saja , akan lebih baik jika dapat membantu keseluruhan proses yang ada pada apotek.

\section{REFERENSI}

Adhawiyah, Y., Kumaladewi, N., \& Caturutami, M. (2017). RANCANG BANGUN SISTEM INFORMASI PENILAIAN KINERJA PEGAWAI MENGGUNAKAN METODE PSYCOLOGICAL APPRAISAL (StudiKasus :Kantor Wilayah Kementerian Agama DKI Jakarta). Studia Informatika: Jurnal Sistem Informasi, 10(2), 119-126.

Afni, N., Pakpahan, R., \& Zaman, I. (2019). Rancang bangun persediaan obat berbasis 
web. Bianglala Informatika, 7(2), 14-21.

Indrawati, S. N. K. (2019). Manajemen Keuangan Perusahaan. Malang: UB Press.

Marina, A., Wahjono, S. I., Syaban, M., \& Suarni, A. (2018). Sistem Informasi Akuntansi: Teori dan Praktikal. Surabaya: UMSurabaya Publishing.

Mulyani, S. (2017). Metode Analisis dan Perancangan SIstem. Bandung: Abdi Sistematika.

Nawang, M., Kurniawati, L., \& Duta, D. (2017). ANCANG BANGUN SISTEM INFORMASI PENGOLAHAN DATA PERSEDIAAN BARANG BERBASIS DEKSTOP DENGAN MODEL. Pilar, 13(2), 233-238.

Rosidin, \& Lubis, B. O. (2017). Implementasi Program Persediaan Barang Pada Cv. Jurnal SIstem Informasi STMIK Antar Bangsa, V(2), 172-180.
Sampeallo, Y. G. (2012). Analisis Pengendalian Persediaan Pada Ud . Bintang. Eksis, 8(1), 2032-2035.

Sari, A. O., \& Nuari, E. (2017). Rancang Bangun Sistem Informasi Persediaan Barang Berbasis Web Dengan Metode Fast(Framework For The Applications). Jurnal PILAR Nusa Mandiri, 13(2), 261-266. Retrieved from http://ejournal.nusamandiri.ac.id/ejurnal/index. php/pilar/article/view/705

Sudradjat, A. (2019). The Development of Student Grades Information System at SDIT Using Waterfall Model. SinkrOn, 3(2), 249. https://doi.org/10.33395/sinkron.v3i2.10049 